\section{A motorized vehicle-mounted sprayer as a new tool for Chagas disease vector control}

\section{Equipamiento aspersor montado en vehículos como nueva herramienta para el control vectorial de la enfermedad de Chagas}

\section{Equipamento aspersor montado em veículo como ferramenta nova para o controle vetorial da doença de Chagas}

\begin{abstract}
Residual insecticide spraying still is the main tool used to suppress house infestations with Chagas disease vectors. While manual compression sprayers (MCS) have traditionally been used in Latin America, Mendoza's vector control program from Argentina introduced the use of a modified motorized vehicle-mounted sprayer (VMS) with apparent advantages over MCS. We conducted a randomized intervention trial to evaluate the effectiveness and selected components of the performance of MCS and VMS. We assessed house infestation by Triatoma infestans in 76 previously-infested houses at 0, 1, 4 and 12 months postintervention. Infestations were reduced substantially, with no significant differences between treatments. End-point infestations were restricted to peridomiciles. Although VMS required less time to complete the house spraying than MCS, both treatments had similar performance and did not suppress infestations completely. The main relative advantages of VMS were a reduced physical effort, especially under harsh field conditions, and potential gains in spray coverage per unit of time.
\end{abstract}

Triatoma; Chagas Disease; Vector Control

\author{
Ana Laura Carbajal-de-la-Fuente 1 \\ Patricia Lencina 2 \\ Cynthia Spillmann 3 \\ Ricardo Esteban Gürtler 1
}

doi: 10.1590/0102-311X00099115

\section{Correspondence}

A. L. Carbajal-de-la-Fuente

Instituto de Ecología, Genética y Evolución de Buenos Aires, Universidad de Buenos Aires.

Intendente Güiraldes 2160, Ciudad Universitaria, Pabellón, Ciudad Autónoma de Buenos Aires C1428EGA, Argentina.

analaura.carbajal@gmail.com

1 Instituto de Ecología, Genética y Evolución de Buenos Aires,

Universidad de Buenos Aires, Buenos Aires, Argentina.

2 Laboratorio de Salud Pública, Ministerio de la Salud de

Mendoza, Mendoza, Argentina.

3 Programa Nacional de Chagas, Ministerio de la Salud,

Córdoba, Argentina. 


\section{Introduction}

Chagas disease or American trypanosomiasis is a neglected tropical disease of great relevance in Latin America. This disease is caused by the protozoan Trypanosoma cruzi (Chagas, 1909), which is mainly transmitted by triatomine bugs (Hemiptera: Reduviidae) and affects 7-10 million people 1. Triatoma infestans (Klug, 1834) is the most important vector in the southern cone countries of South America. Although its historical-geographical distribution has been strongly reduced, this species still persists in the Gran Chaco eco-region of Argentina, Bolivia and Paraguay where it represents an important health problem 2,3,4. Its persistence is strongly linked to poverty and various socio-political, ecological and biological determinants 5,6,7

Intergovernmental Chagas disease control initiatives launched in Latin America during the 1990s pursued the elimination of T. cruzi transmission by blood transfusion and by domestic populations of triatomine bugs 4 . Screening of blood donors and vector control actions dramatically reduced the human prevalence of $T$. cruzi infection and the population at risk. In the absence of an effective vaccine, residual insecticide spraying still is the main or only tool used to suppress domestic populations of triatomines and remains the most cost-effective strategy 8,9. The protocols and methodologies for vector control and evaluation were standardized in the 1960s 10. Since the advent of pyrethroid insecticides in the 1980s, the complete suppression of domestic population of triatomines was considered to be technically feasible 11,12 .

The World Health Organization issued specifications for major equipment used to apply insecticides for vector control 13. For Chagas disease, insecticides have usually been applied with manual compression sprayers (MCS). In Argentina, the Chagas control program of Mendoza province recently introduced the use of a modified motorized vehicle-mounted sprayer (VMS) for insecticide application, which, according to their extensive field experience, was considered more advantageous than the traditional MCS. However, the relative effectiveness and performance of both treatments have not been investigated, and there is no other published record of the use of VMS for triatomine bug control.

Effectiveness and efficiency are key in assessing and measuring performance 14. Effectiveness is associated with the degree of success in achieving one specified task, whereas efficiency takes into account the relationship between the degree of effectiveness and the variable "cost" associated (i.e., time, effort, or money demanded by the intended task). The time spent to perform a task is the most common component of performance used to compare the efficiency of different gears 14 .

The Argentinian Ministry of Health has classified Mendoza province as a high-risk area on the basis of high seroprevalence of T. cruzi in vulnerable population groups and the (re-)emergence of vector-borne transmission in the recent past 15 . As part of a broader study on the eco-epidemiology and control of Chagas disease in Mendoza province, we performed a small-scale, randomized intervention trial aiming to evaluate the effectiveness and selected components of the performance of spraying with MCS and VMS.

\section{Material and methods}

\section{Study area}

Fieldwork was conducted in a rural area of Lavalle Department (32 29.731S, 68 09.467W) in Mendoza province, Argentina (Figure 1), between May 2013 and May 2014. This region belongs to the "Monte" (scrubland) biogeographic province; the climate is semiarid and presents xeric-scrubland vegetation 16. Local meteorological data were obtained from Telteca station (http://www.cricyt.edu. ar/ladyot/red_iadiza/datos/telteca/telteca_05_13.pdf). Mean monthly temperatures and precipitation were, respectively, $12.1^{\circ} \mathrm{C}$ (range, $-7.2^{\circ} \mathrm{C}$ to $28.3^{\circ} \mathrm{C}$ ) and $0 \mathrm{~mm}$ in May $2013 ; 8.6^{\circ} \mathrm{C}$ (range, $-9.1^{\circ} \mathrm{C}$ to $25.4^{\circ} \mathrm{C}$ ) and $1.8 \mathrm{~mm}$ in June $2013 ; 12.9^{\circ} \mathrm{C}$ (range, $-8.7^{\circ} \mathrm{C}$ to $39.6^{\circ} \mathrm{C}$ ) and $0 \mathrm{~mm}$ in September 2013 ; and $12.0^{\circ} \mathrm{C}$ (range, $-5.9^{\circ} \mathrm{C}$ to $25.0^{\circ} \mathrm{C}$ ) and $2.6 \mathrm{~mm}$ in May 2014. Temperatures recorded in situ during the insecticide spraying operations averaged $20.4 \pm 0.9^{\circ} \mathrm{C}$, and wind speed was $1.5 \pm 0.3(\mathrm{~m} / \mathrm{s})$. A slight drizzle occurred only once but no domiciliary unit was treated on that day. Vector control activities 
Figure 1

Study area in Lavalle Department (black dot), Mendoza Province, Argentina.
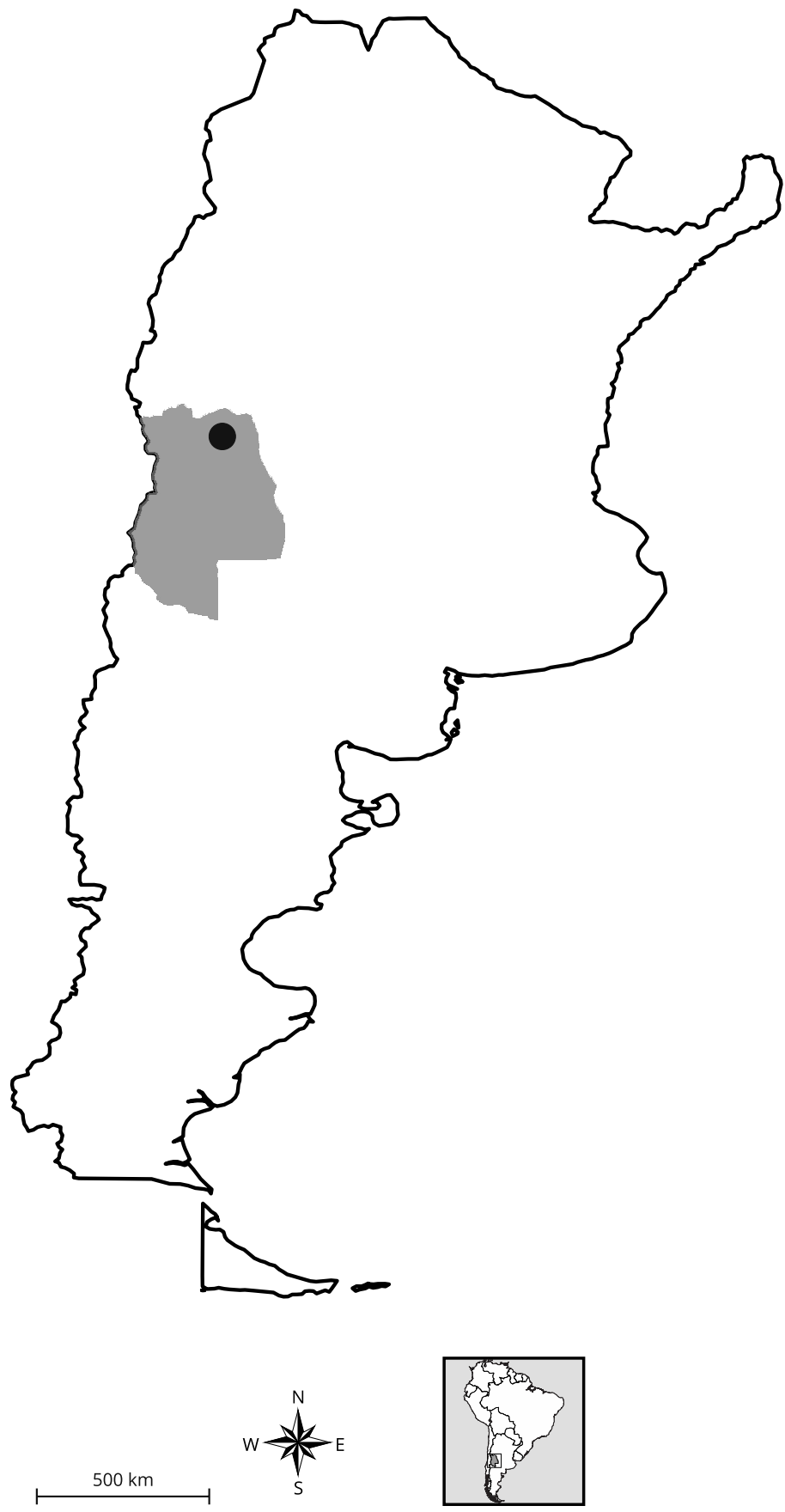

in this area had historically been very sporadic, and the last insecticide spraying campaign had been carried out between two and 10 years before the present trial. 


\section{Study design}

Before interventions, experienced field personnel of the National Vector Control Program (NVCP) from Mendoza province detected 76 (25\%) domiciliary units infested with T. infestans after a thorough inspection of 198 domiciliary units in the study area in April 2013. These 76 domiciliary units included in the current trial were scattered within $1,400 \mathrm{~km}^{2}$, with between-house distances of a few hundred meters up to $50 \mathrm{~km}$. The domiciliary unit is taken to include human sleeping quarters (i.e., intradomicile) and its surrounding annexes regardless of distance to the former (i.e., peridomicile).

The randomized intervention trial was divided into two phases: (i) another vector survey of the 76 infested domiciliary units in May 2013, immediately followed by insecticide spraying, and (ii) monitoring of postintervention infestation in June and September 2013 and May 2014. The remaining uninfested domiciliary units $(\mathrm{n}=222)$, not included in the intervention trial, were all sprayed with insecticides during May-June 2013 using MCS.

\section{The randomized intervention trial}

Fieldwork was conducted by four teams of three people each, which included two skilled bug collectors from NVCP (responsible for triatomine searches and insecticide application) and a third member (who supervised the operations and collected environmental and demographic data). An adult member of each domiciliary unit was interviewed to explain the aim and phases of the project. Each house was identified with a sticker and geo-referenced with a GPS receiver (Garmin Legend). All houses were searched for triatomines in intradomicile and peridomicile sites using timed manual collections (TMC) conducted by two persons during $30 \mathrm{~min}$ per house (i.e., one person-hour per house) and a dislodging aerosol ( $0.2 \%$ tetramethrin, Espacial, Reopen, Buenos Aires, Argentina). Triatomines were placed in labeled plastic bags according to the capture site and transported to the laboratory. Species were identified according to Lent \& Wygodzinsky 17.

The 76 domiciliary unit were randomly assigned for treatment with either VMS (Malanca S.R.L., Argentina, adapted and modified by NVCP personnel) or MCS (Zealin Sprayer, China). Forty-one domiciliary units were sprayed with VMS and 35 domiciliary units were sprayed with MCS. To evaluate treatment performance, for each domiciliary unit we registered the total sprayed area, amount of insecticide applied (in monodoses of $250 \mathrm{~mL}$ ), water consumed, and time to complete the insecticide spray - including preparation of equipment from start to end - in a standard form. To evaluate treatment effectiveness we considered the reduction in the prevalence of infestation and abundance of $T$. infestans over time.

All the inner surfaces of the house and the external sides of the walls and all the peridomestic structures (corrals, storage places, etc.) were sprayed with $2.5 \%$ suspension concentrate deltamethrin at concentrations of $25 \mathrm{mg} / \mathrm{m}^{2}$ (K-Othrina, Bayer, Munro, Argentina) following standard protocols 18 . Householders did not allow access to the intradomicile in one domiciliary unit, and therefore only the peridomestic structures were sprayed; this intradomicile was excluded from the analysis.

Each of the 76 domiciliary units sprayed with insecticides was re-inspected for the presence of triatomine bugs at one (June 2013), four (September 2013) and 12 months (May 2014) postintervention using the same protocol. All domiciliary units positive by timed manual collections after the initial insecticide spraying were considered 'reinfested' and re-sprayed immediately with the same treatment.

\section{Data analysis}

The overall prevalence of infestation postintervention was estimated for domiciliary unit that were sprayed with insecticides and evaluated at least once after initial spraying. A domiciliary unit was considered infested when at least one live or moribund $T$. infestans bug was collected in any site. Comparisons of the performance-related variables between treatments were performed through a $t$ test as implemented in JMP v 6.0.0 (SAS Inst., Cary, U.S.A.). Between-treatment comparisons of the abundance of bugs and house infestation were investigated via a median test and through the estimation of difference of proportions, respectively, as implemented in Infostat (Grupo InfoStat, Universidad Nacional de Córdoba. http://www.infostat.com.ar/). 


\section{Results}

\section{Effectiveness}

House infestation and total abundance of T. infestans during the intervention trial are shown in Figure 2. Insecticide spraying reduced house infestations from $100 \%$ to $21 \%, 0 \%$ and $8 \%$ at $0,1,4$ and 12 months postintervention, respectively. End-point infestations were restricted to peridomestic habitats. Bug abundance did not differ significantly between treatments at 0, 1, 4 and 12 months postintervention (median test, p-value $>0.05$ ).

Before interventions (month 0 ), we detected a high abundance of adults and nymphs of T. infestans $(\mathrm{n}=1,686)$ in domestic and peridomestic sites. T. infestans was found in domestic and/or peridomestic habitats of 41 (53.9\%) domiciliary units (Table 1). A kennel with four dogs adjacent to a chicken coop harbored a large colony of $T$. infestans $(\mathrm{n}=708)$. This kennel was approximately $30 \mathrm{~m}$ from human sleeping quarters and $100 \mathrm{~m}$ from the nearest neighboring house. A few adult and nymphal specimens ( $\mathrm{n}=11$ ) of T. platensis Neiva, 1913, were captured at two domiciliary units, mainly in chicken coops.

A drastic reduction in the abundance of T. infestans was recorded one month postintervention (Table 1). However, a total of 149 adults and nymphs were collected in domestic premises (mainly bedrooms) and peridomestic sites (goat corrals and rabbit hutches). All of the 16 domiciliary units infested with T. infestans at one month postintervention had been infested at month 0 . Two T. platensis were captured in chicken coops at one domiciliary unit.

No triatomine was found at four months postintervention, in late winter (Table 1). At 12 months postintervention, adults and nymphs of $T$. infestans $(n=37)$ were collected exclusively in peridomestic sites from 6 domiciliary units. Two of them had also been positive for T. infestans at month 0 (both

\section{Figure 2}

Effectiveness of insecticide spraying applications using vehicle-mounted automatic sprayers (VMS) versus manual compression sprayers (MCS) as measured by house infestation and total abundance of $T$. infestans in 76 houses from Lavalle Department (Mendoza, Argentina) between May 2013-2014. Arrows represent the initial insecticide spray (at month 0) and the selective sprays (at 1 and 12 months postintervention).

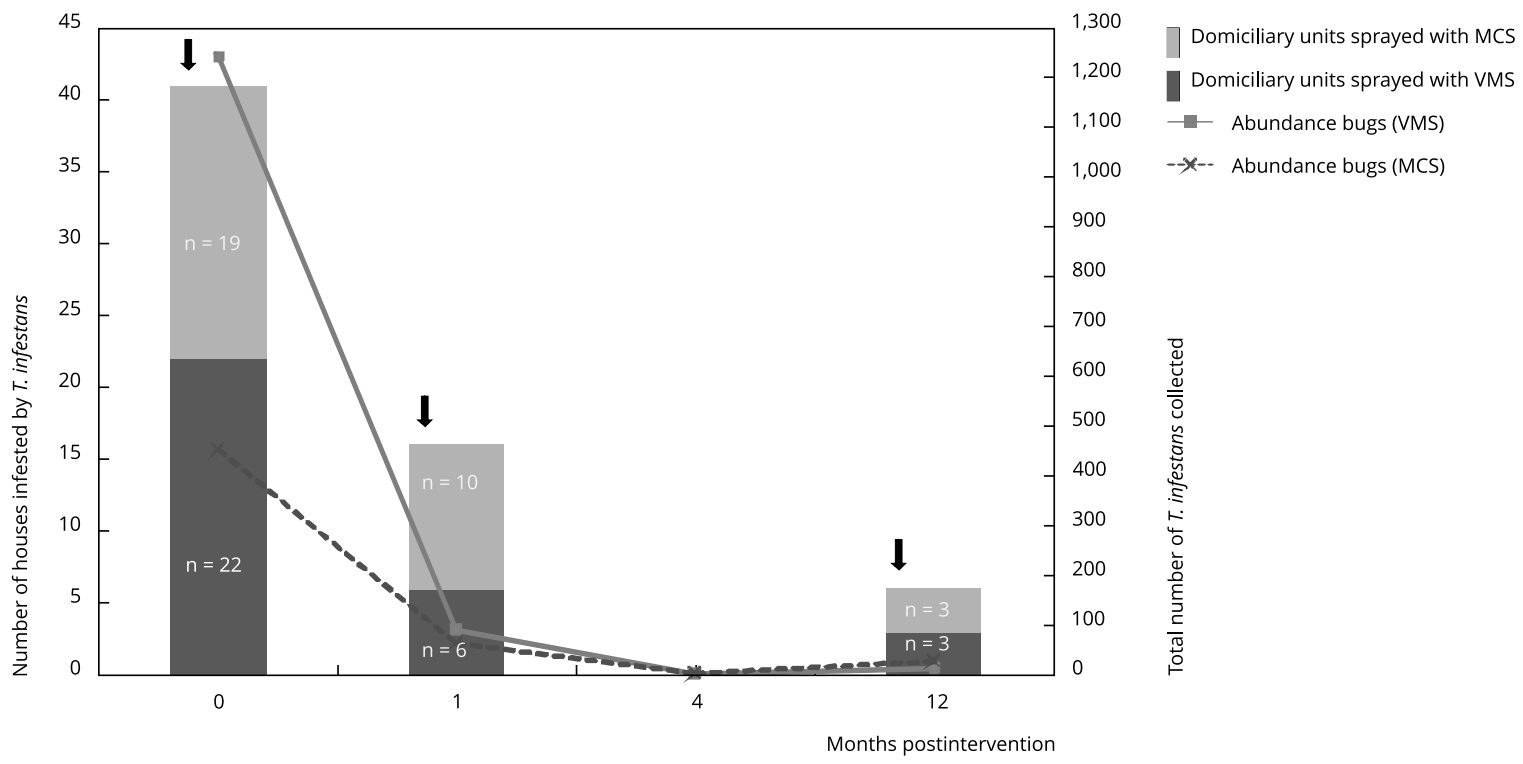




\section{Table 1}

Entomological results of surveys conducted at month 0 (May 2013), 1 (June 2013), 4 (September 2013) and 12 months (May 2014) after initial spraying with pyrethroid insecticides of 76 houses at Lavalle Department, Mendoza, Argentina.

\begin{tabular}{|c|c|c|c|c|}
\hline \multirow[t]{2}{*}{ Variables } & \multicolumn{4}{|c|}{ Domiciliary units surveyed at [months postintervention] } \\
\hline & 0 & 1 & 4 & 12 \\
\hline Number of infested houses at intradomicile & $3(3.9)$ & $5(6.5)$ & $0(0.0)$ & $0(0.0)$ \\
\hline Number of infested houses at peridomicile & $31(40.7)$ & $10(13.1)$ & $0(0.0)$ & $6(7.8)$ \\
\hline Number of infested houses at intradomicile and peridomicile & $7(9.2)$ & $1(1.3)$ & $0(0.0)$ & $0(0.0)$ \\
\hline Number of infested houses with $T$. infestans & $41(53.9)$ & $16(21.0)$ & $0(0.0)$ & $6(7.8)$ \\
\hline Number of $T$. infestans collected by TMC & 1,686 & 149 & 0 & 37 \\
\hline
\end{tabular}

TMC: timed-manual collections

at peridomestic sites) whereas the remaining four domiciliary units were found infested for the first time during the follow-up. A rabbit hutch was the only structure persistently infested throughout the 12-month period. Five specimens of T. patagonica Del Ponte, 1929, were captured in a chicken coop.

Figure 2 shows no significant differences in effectiveness between treatments $\left(\chi^{2}=0.0084, \mathrm{df}=1\right.$, $\mathrm{p}$-value $=0.97$ ). In spite of the dramatic reduction of infestation recorded at one month postintervention, three domiciliary units that had been sprayed with VMS and three treated with MCS still were infested. At 12 months postintervention four domiciliary units that had been sprayed with VMS and four treated with MCS were infested.

\section{Performance}

Table 2 shows medians and quartiles obtained for sprayed surface, the number of insecticide doses, liters of water consumed, and time spent to complete the spraying according to type of treatment. The VMS treatment was slightly faster than MCS indoors (intradomicile), and more so in peridomicile and in both habitats combined (Table 2). The $t$ test did not show significant differences in the total number of insecticide doses used per volume of water consumed and sprayed surface (results not shown) between treatments.

\section{Discussion}

This study provides information about the performance of modern spray equipments that vector control programs may use to suppress (peri)domestic infestations with triatomine bugs. The trial also provided updated information on the occurrence of house infestation with $T$. infestans and other triatomine species in northern Mendoza province, documenting high bug abundance in domestic and peridomestic sites. Peridomestic (re)infestation by T. infestans has been documented elsewhere in the Gran Chaco ecoregion 19,20,21,22,23,24 but not in Mendoza province.

Our results show that both the VMS and MCS achieved similar degrees of effectiveness and performance regarding vector control up to 12 months postintervention. Both treatments did not completely suppress infestations despite selective treatments after the initial, full-coverage intervention. Although most of the treated bug colonies declined dramatically (between May and June 2013) or were apparently suppressed by the end of winter (September 2013), six months later infestations were again detected at the same or in new peridomestic sites after the spring-summer period (in May 2014). Thus, house infestation (7.8\%) at 12 months postintervention exceeded the target level of a successful control intervention (i.e., $<5 \%$ of infested houses within 6-12 months after full-coverage house spraying with pyrethroids) 18 .

In addition to insecticide effects, the initial reduction of apparent infestation during the autumnwinter period (May-September) may in part be attributed to the steep decrease in minimum 
Table 2

Performance of insecticide spraying operations using manual compression versus vehicle-mounted sprayers in houses from Lavalle Department, Mendoza, Argentina, evaluated during May 2013.

\begin{tabular}{|c|c|c|c|c|c|c|c|c|}
\hline \multirow[t]{2}{*}{ Habitat } & \multicolumn{4}{|c|}{ Manual compression sprayer } & \multicolumn{4}{|c|}{ Vehicle-mounted sprayer } \\
\hline & $\begin{array}{l}\text { Area sprayed } \\
\qquad\left(\mathrm{m}^{2}\right)\end{array}$ & $\begin{array}{l}\text { Insecticide } \\
\text { monodose } \\
\text { (N) }\end{array}$ & $\begin{array}{l}\text { Water } \\
\text { (Litre) }\end{array}$ & $\begin{array}{l}\text { Time } \\
\text { (min) }\end{array}$ & $\begin{array}{c}\text { Area sprayed } \\
\qquad\left(\mathrm{m}^{2}\right)\end{array}$ & $\begin{array}{l}\text { Insecticide } \\
\text { monodose } \\
\text { (N) }\end{array}$ & $\begin{array}{l}\text { Water } \\
\text { (Litre) }\end{array}$ & $\begin{array}{l}\text { Time } \\
(\min )\end{array}$ \\
\hline \multicolumn{9}{|l|}{ Intradomicile } \\
\hline Median & 311.1 & 4 & 16 & 40 & 288.2 & 5 & 20 & 35 \\
\hline Q (25-75) & 214.8-389.9 & $3-6$ & $12-24$ & $26.5-55.3$ & $223.6-374.5$ & $4.0-6.0$ & $15.0-24.0$ & $26.3-47.3$ \\
\hline $\mathrm{n}$ & 32 & 31 & 31 & 32 & 40 & 27 & 40 & 40 \\
\hline \multicolumn{9}{|l|}{ Peridomicile } \\
\hline Median & 236.3 & 6 & 24 & 45 & 216 & 7 & 25 & 37.5 \\
\hline $\mathrm{Q}(25-75)$ & $120-455$ & $4.00-8.25$ & $16-33$ & $30-65$ & $149.8-412.8$ & $5.0-8.8$ & $15.8-32.0$ & $23.0-57.8$ \\
\hline $\mathrm{n}$ & 31 & 30 & 30 & 31 & 38 & 25 & 38 & 38 \\
\hline \multicolumn{9}{|l|}{ Intradomicile } \\
\hline \multicolumn{9}{|c|}{+ peridomicile } \\
\hline Median & 646.2 & 9 & 36 & 90 & 530 & 12 & 42 & 73 \\
\hline Q (25-75) & 466.3-732.9 & $8-14$ & $28-56$ & $60-120$ & 401.6-777.9 & 914 & $33.5-53.5$ & $55.5-96.0$ \\
\hline $\mathrm{n}$ & 32 & 32 & 32 & 32 & 41 & 41 & 41 & 41 \\
\hline
\end{tabular}

$\mathrm{n}$ : number of observations for each variable.

temperatures (ranging from $7.2^{\circ} \mathrm{C}$ to $-5.9^{\circ} \mathrm{C}$ in May 2013 and May 2014, respectively), which is expected to reduce both bug survival and the detectability of bugs by timed-manual searches. In addition, given the cool weather period elapsed between the insecticide spray and the first assessment of house infestation one-month postintervention (during which bug activity presumably declined), it is likely that some of the bugs collected then might have been intoxicated by the insecticide and were yet to die 25 , as some of the field technicians reported. However, after the hot summer season, peridomestic colonies of $T$. infestans were again detected; some of these occurred in previously infested sites that had been re-sprayed with insecticides, and therefore were putative residual foci.

The apparent reduction of house infestation by T. infestans between April and May 2013 (prior to insecticide spraying) may be associated with large drops in bug population size after removal of insects (especially in houses where the apparent bug density was low) combined with the limited sensitivity of timed manual collections, which is clearly dependent on bug collectors' skills, capture effort, search conditions, and detection errors. Detection errors (overlooking infestations or spurious detection) may affect overall infestation measures and other commonly-used entomological indices (i.e., intradomicile and peridomicile infestation, colonization, density, dispersion, or natural infection by T. cruzi), and therefore may appear to be control failures 26 .

House reinfestation after residual insecticide spraying may be explained by different processes: (i) incomplete spray coverage of target sites causing control failures; (ii) low susceptibility to the insecticide; and (iii) extradomiciliary, residual or wild foci of T. infestans 22,27,28,29. Regarding (i), the presence of residual foci of $T$. infestans can be inferred from the coincidence of sites persistently infested before and after insecticide sprays, mainly occurring in large, structurally complex peridomestic structures such as goat corrals 27,30. Some of the residual foci detected indoors may likely be due to insufficient mobilization of household goods, bags and other objects at the time of insecticide application. It is unlikely that these foci originated from other previously uninfested domiciliary unit because the entire area was sprayed with pyrethroids during the intervention period.

Regarding reduced susceptibility to the insecticide (ii), pyrethroid resistance in T. infestans has been reported in several provinces including Guaymallén, Mendoza 31,32,33,34. However, triatomines collected at the Lavalle study area showed no evidence of pyrethroid resistance ${ }^{35}$. Regarding bug 
immigration from external sources (iii), house reinfestation may derive from the intrusion of sylvatic adult bugs followed by house colonization. Wild foci of T. infestans have been found in Argentina 29,36, Bolivia 28,37,38, Chile 39, and Paraguay 40. In Mendoza province, after the initial finding of T. infestans in wild habitats by Mazza et al. ${ }^{41}$, no further reports on this matter were made. Because sylvatic populations of $T$. infestans have the potential to jeopardize control efforts 28 , further research on this subject is needed.

Searches for improved control strategies of triatomines included biological 42 , socio-cultural 43 , environmental management 30, and technical aspects of insecticide applications 44,45. The VMS was slightly faster than MCS indoors and was not affected by some limitations (sensu 12) of the MCS, such as the imprecision of the manometer, and the need to pump several times during spraying to maintain the pressure between 40 and $60 \mathrm{kPa}$. The VMS has the manometer incorporated and the pressure is controlled to exactly $60 \mathrm{kPa}$ as recommended 13 . Because the VMS is mounted on a vehicle, the operator's physical effort is very much reduced, especially under harsh field conditions. Unlike the MCS (which weighs $24 \mathrm{~kg}$ when fully loaded), the VMS technician only carries a hose and may move more easily between target sites; labor-related injuries associated with weight transport are therefore prevented. Despite that both pieces of equipment exhibited similar performance, the VMS contributed remarkably to facilitate the spray task. Reducing human effort and improving fieldwork conditions may facilitate the elimination of (peri)domestic populations of T. infestans.

One disadvantage of the VMS tank is that its capacity (150-Litre) is graduated at 10-Litre intervals, which does not comply with the recommended standard (5-Litre intervals) for large tanks 13 . Another limitation of this study is that the amount of insecticide applied on the surface was not quantified. Interpretation of our results is limited by lack of information on the amount of insecticide residue on the sprayed surfaces. However, both pieces of equipment used the same lance, control flow valves and nozzles according to current recommendations 13 , and therefore the pace at which the spray is to be conducted equals the one employed by spray teams equipped with MCS. In view of the results herein reported, more detailed trials that additionally measure the amount of insecticide residue on sprayed surfaces are warranted. Estimates of the cost of both treatments are needed to identify the most costeffective operational procedure and make an informed decision.

The sustained elimination of T. infestans from large sections of the Gran Chaco and neighboring regions has not been met, even in areas subject to intensive, professional vector control efforts 3 . The reasons for the limited effectiveness appear to be multiple and need further clarification. In rural areas from Mendoza, the difficulty of eliminating T. infestans may be explained by the effects of large peridomestic structures (e.g., corrals) that provide refuges for the bugs, and the presence of highdensity bug infestations. The incomplete spray coverage of target sites may also contribute to the occurrence of residual foci that become detectable as adequate temperatures and bug population size increase. Vector control activities in the affected region need to be intensified and coordinated with governmental agencies, non-governmental organizations, academia and the affected communities. 


\section{Contributors}

A. L. Carbajal-de-la-Fuente conceived and designed the trial, performed field work and processed the biological material, analyzed the data, contributed with materials and equipment and wrote the paper. P. Lencina contributed with materials and equipment and read and approved the final version of the manuscript. C. Spillmann analyzed the data, contributed with materials and equipment and read and approved the final version of the manuscript. R. E. Gürtler conceived and designed the trial, analyzed the data, contributed with materials and equipment and wrote the paper.

\section{Acknowledgments}

We are grateful to all the Lavalle families for collaborating with this study. We thank the National Chagas Control Program personnel and local health workers for their valuable assistance in field work; A. Pedraza and G. Pizzarello for collaboration in laboratory work; G. Mougabure-Cueto for conducting insecticide resistance tests, J. Nattero, R. Piccinali, H. Falcone, L. Rodriguez Planes, P. Fernandez, M. Orozco, C. Cecere, S. Gaspe and Y. Provecho for helpful suggestions. This study was supported by the National Chagas Disease Control Program, National Health Ministry, Córdoba; Division of Zoonoses, Vectors and Reservoirs, Health Ministry, Mendoza; TechnologicalTechnologic and Social Development Projects (PDTS-PX03), Ministry of Science, Technology and Productive Innovation and University of Buenos Aires and Agencia Nacional de Promoción Científica y Tecnológica (PICT 2013-2538 and 2014-3746), Argentina. A.L.C.F. and R.E.G. are members of the CONICET Researcher Career.

\section{References}

1. World Health Organization. Chagas disease (American trypanosomiasis). http://www.who.int/media centre/factsheets/fs340/en/ (accessed on 16/Jun/ 2015).

2. Dias JC. Southern Cone Initiative for the elimination of domestic populations of Triatoma infestans and the interruption of transfusional Chagas disease. Historical aspects, present situation, and perspectives. Mem Inst Oswaldo Cruz 2007; 102:111-8.

3. Gürtler RE. Sustainability of vector control strategies in the Gran Chaco region: current challenges and possible approaches. Mem Inst Oswaldo Cruz 2009; 104:52-9.

4. World Health Organization. Chagas disease in Latin America: an epidemiological update based on 2010 estimates. Geneva: World Health Organization; 2015. (WHO Report 2015).

5. Chagas C. Nova tripanozomiaze humana: estudos sobre a morfolojia e o ciclo evolutivo do Schizotrypanum cruzi n. gen., $n$. sp., ajente etiolojico de nova entidade morbida do homem. Mem Inst Oswaldo Cruz 1909; 1:159-218.

6. Dumonteil E, Nouvellet P, Rosecrans K, RamirezSierra MJ, Gamboa-León R, Cruz-Chan S, et al. Eco-bio-social determinants for house infestation by non-domiciliated Triatoma dimidiata in the Yucatan Peninsula, Mexico. PLoS Negl Trop Dis 2013; 7:e2466.

7. Ventura-Garcia L, Roura M, Pell C, Posada E, Gascon J, Aldasoro E, et al. Socio-cultural aspects of Chagas disease: a systematic review of qualitative research. PLoS Negl Trop Dis 2013; 7:e2410.

8. Pan American Health Organization. Enfermedad de Chagas. http://www.paho.org/hq/index. php?option $=$ com_topics\&view $=$ article $\&$ id $=10 \& I t$ emid=40743\&lang=es (accessed on 06/Apr/2015).

9. Waleckx E, Gourbière S, Dumonteil E. Intrusive versus domiciliated triatomines and the challenge of adapting vector control practices against Chagas disease. Mem Inst Oswaldo Cruz 2015; 110:324-38.

10. Schofield C. Field testing and evaluation of insecticides for inddor residual spraying against domestic vectors of Chagas disease. http://www.who.int/ whopes/gcdpp/publications/en/index3.html (accessed on 16/Jun/2015).

11. Dias JC, Schofield C. The evolution of Chagas disease (American Trypanosomiasis) control after 90 years since Carlos Chagas discovery. Mem Inst Oswaldo Cruz 1999; 94:103-21.

12. World Health Organization. Control of Chagas disease. Geneva: World Health Organization; 2002. (WHO Report 2002).

13. World Health Organization. Equipment and application. http://www.who.int/whopes/equipment/ en/ (accessed on 16/Jun/2015).

14. Dal B, Tugwell P, Greatbanks R. Overall equipment effectiveness as a measure of operational improvement: a practical analysis. International Journal of Operations \& Production Management 2000; 20:1488-502. 
15. Ministerio de Salud. Diagnóstico de situación. http://www.msal.gov.ar/chagas/index.php/institucional/diagnostico (accessed on 16/Jun/2015).

16. Roig FA, Roig-Juñent S, Corbalán S. Biogeography of the monte desert. J Arid Environ 2009; 73: 164-72.

17. Lent H, Wygodzinsky P. Revision of the Triatominae (Hemiptera: Reduviidae), and their significance as vectors of Chagas disease. Bulletin of the American Museum of Natural History 1979; 163:123-520.

18. Ministerio de Salud. Guia de-control vectorial. http://www.msal.gov.ar/chagas/index.php/infor macion-para-equipos-de-salud/guia-de-controlvectorial (accessed on 16/Jun/2015).

19. Cecere MC, Gürtler RE, Chuit R, Cohen J. Effects of chickens on the prevalence of intestation and population density of Triatoma infestans in rural houses of north-west Argentina. Med Vet Entomol 1997; 11:383-8.

20. Rojas de Arias A, Russomando G. El control de la enfermedad de Chagas en Paraguay. In: Silveira A, editor. El control de la enfermedad de Chagas en los paises del cono sur de America. Uberaba: Organización Panamericana de la Salud; 2002. p. 269-98.

21. Dohna HZ, Cecere MC, Gürtler RE, Kitron U, Cohen J. Re-establishment of local populations of vectors of Chagas disease after insecticide spraying. J Appl Ecol 2007; 44:220-7.

22. Gurevitz JM, Gaspe MS, Enriquez GF, Provecho YM, Kitron U, Gürtler RE. Intensified surveillance and insecticide-based control of the chagas disease vector Triatoma infestans in the Argentinean Chaco. PLoS Negl Trop Dis 2013; 7:e2158.

23. Hernández ML, Dujardin JP, Gorla DE, Catalá SS. Potential sources of Triatoma infestans re-infesting peridomicilies identified by morphological characterization in Los Llanos (La Rioja, Argentina). Mem Inst Oswaldo Cruz 2013; 107:91-7.

24. Samuels AM, Clark EH, Galdos-Cardenas G, Wiegand RE, Ferrufino L, Menacho S, et al. Epidemiology of and impact of insecticide spraying on Chagas disease in communities in the Bolivian Chaco. PLoS Negl Trop Dis 2013; 7:e2358.

25. Colas R, Delabarre M. Control of vectors of the main endemic disease. In: Roussel U, editor. Deltamethrin, Monograph. Paris: Hardcover; 1982. p. 259-71.

26. Abad-Franch F, Valença-Barbosa C, Sarquis O, Lima MM. All that glisters is not gold: samplingprocess uncertainty in disease-vector surveys with false-negative and false-positive detections. PLoS Negl Trop Dis 2014; 8:e3187.

27. Gürtler RE, Canale DM, Spillmann C, Stariolo R, Salomón OD, Blanco S, et al. Effectiveness of residual spraying with deltamethrin and permethrin on peridomestic populations of Triatoma infestans in rural western Argentina: a district-wide randomized trial. Bull World Health Organ 2004; 82:196-205.

28. Noireau F, Cortez MR, Monteiro FA, Jansen AM, Torrico F. Can wild Triatoma infestans foci in Bolívia jeopardize Chagas disease control efforts? Trends Parasitol 2005; 21:7-10.
29. Ceballos LA, Piccinali RV, Marcet PL, VazquezProkopec GM, Cardinal MV, Schachter-Broide $\mathrm{J}$, et al. Hidden sylvatic foci of the main vector of Chagas disease Triatoma infestans: threats to the vector elimination campaign? PLoS Negl Trop Dis 2011; 50:e1365.

30. Gorla DE, Abrahan L, Hernandez ML, Porcasi X, Hrellac HA, Carrizo H, et al. New structures for goat corrals to control peridomestic populations of Triatoma infestans (Hemiptera: Reduviidae) in the Gran Chaco of Argentina. Mem Inst Oswaldo Cruz 2013; 108:352-8.

31. Gonzalez Audino P, Vassena C, Barrios S, Zerba E, Picollo MI. Role of enhanced detoxicationin a deltamethrin-resistant population of Triatoma infestans (Hemiptera, Reduviidae) from Argentina. Mem Inst Oswaldo Cruz 2004; 99:335-9.

32. Picollo MI, Vassena CV, Santo Orihuela P, Barrios S, Zaidemberg M, Zerba EN. High resistance to pyrethroid insecticides associated with ineffective field treatments in Triatoma infestans (Hemiptera: Reduviidae) from Northern Argentina. J Med Entomol 2005; 42:637-42.

33. Germano MD, Roca Acevedo G, MougabureCueto G, Toloza AC,Vassena CV, Picollo MI. New findings of insecticide resistance in Triatoma infestans (Heteroptera: Reduviidae) from the Gran Chaco. J Med Entomol 2010; 47:1077-108.

34. Germano MD. Herencia y efectos demográficos de la resistencia a deltametrina en Triatoma infestans [PhD Thesis]. Buenos Aires: Universidad de Buenos Aires; 2013.

35. Fronza G, Toloza AC, Picollo MI, Spillmann C, Mougabure Cueto C. Geographical variation of deltamethrin susceptibility of Triatoma infestans (Hemiptera: Reduviidae) in Argentina with emphasis on a resistant focus in the Gran Chaco. J Med Entomol 2016; 53:880-7.

36. Ceballos LA, Piccinali RV, Berkunsky I, Kitron U, Gürtler RE. First finding of melanic sylvatic Triatoma infestans (Hemiptera: Reduviidae) colonies in the Argentine Chaco. J Med Entomol 2009; 46:1195-202.

37. Noireau F, Flores R, Gutierrez T, Abad-Franch F, Flores E, Vargas F. Natural ecotopes of Triatoma infestans dark morph and other wild triatomines in the Bolivian Chaco. Trans R Soc Trop Med Hyg 2000; 94:23-7.

38. Waleckx E, Depickère S, Salas R, Aliaga C, Monje M, Calle H, et al. New discoveries of sylvatic Triatoma infestans (Hemiptera: Reduviidae) throughout the Bolivian Chaco. Am J Trop Med Hyg 2012; 86:455-8

39. Bacigalupo A, Torres-Pérez F, Segovia V, García A, Correa JP, Moreno L, et al. Sylvatic foci of the Chagas disease vector Triatoma infestans in Chile: description of a new focus and challenges for control programs. Mem Inst Oswaldo Cruz 2010; 105:633-41.

40. Rolón M, Vega MC, Román F, Gómez A, Rojas de Arias A. First report of colonies of sylvatic Triatoma infestans (Hemiptera: Reduviidae) in the Paraguayan Chaco, using a trained dog. PLoS Negl Trop Dis 2011; 3:e1026. 
41. Mazza S, Basso G, Basso R. Hallazgos de Triatoma platensis en nidos de Dendrocolaptidae de las provincias de Córdoba y Mendoza. Demostración experimental de la capacidad de transimitir Schizotrypanum cruzi de esta especie de triatomideo. Misión de Estudios de Patología Regional Argentina 1936; 29:18-21.

42. Forlani L, Juárez MP, Lavarías S, Pedrini N. Toxicological and biochemical response of the entomopathogenic fungus Beauveria bassiana after exposure to deltamethrin. Pest Manag Sci 2014; 70:751-6.

43. Monroy C, Bustamante DM, Pineda S, Rodas A, Castro X, Ayala V, et al. House improvements and community participation in the control of Triatoma dimidiata re-infestation in Jutiapa, Guatemala. Cad Saúde Pública 2009; 25 Suppl 1:S168-78.

\section{Resumen}

El empleo de insecticida residual es todavía la principal herramienta para suprimir la infestación domiciliaria por triatominos, vectores de la enfermedad de Chagas. Mientras los aspersores manuales activados por compresión han sido utilizados tradicionalmente en América Latina, el programa de control vectorial de la provincia de Mendoza, Argentina, introdujo el uso de un equipamiento aspersor montado en un vehículo, aparentemente con ventajas respecto al aspersor manual. Realizamos un ensayo de intervención aleatorizado para evaluar la efectividad y los componentes seleccionados del desempeño de los dos equipamientos. Evaluamos la infestación por Triatoma infestans en 76 vivendas, previamente infestados a 0, 1, 4 y 12 meses tras la intervención. Las infestaciones se redujeron substancialmente, sin diferencia significativa entre las dos técnicas. Las infestaciones finales se limitaban al peridomicilio. El equipamiento montado en el vehículo llevaba menos tiempo para completar la aplicación, comparado con el equipamiento manual, pero los dos tratamientos tuvieron un desempeño semejante y dejaron de suprimir completamente las infestaciones. Las principales ventajas del equipamiento montado en vehículo fueron: la reducción del esfuerzo físico, principalmente en condiciones adversas en el campo, y potenciales beneficios en términos de cobertura de pulverización por unidad de tiempo.

Triatoma; Enfermedad de Chagas; Control de Vectores
44. Ferral J, Chavez-Nuñez L, Euan-Garcia M, Ramirez-Sierra MJ, Najera-Vazquez V, Dumonteil E. Comparative field trial of alternative vector control strategies for non-domiciliated Triatoma dimidiata. Am J Trop Med Hyg 2010; 82:60-6.

45. Cecere MC, Vázquez-Prokopec GM, Ceballos LA, Boragno S, Zárate JE, Kitron U, et al. Improved chemical control of Chagas disease vectors in the dry Chaco region. J Med Entomol 2013; 50:394-403.

\section{Resumo}

A aplicação de inseticida residual ainda é a principal medida para suprimir a infestação domiciliar por triatomíneos, vetores da doença de Chagas. Enquanto os aspersores manuais acionados por compressão têm sido utilizados tradicionalmente na América Latina, o programa de controle vetorial da Província de Mendoza, Argentina, introduziu o uso de um equipamento aspersor montado em veículo, aparentemente com vantagem em relação ao aspersor manual. Realizamos um estudo randomizado de intervenção para avaliar a efetividade e os componentes selecionados do desempenho dos dois equipamentos. Avaliamos a infestação por Triatoma infestans em 76 domicílios previamente infestados a 0, 1, 4 e 12 meses pósintervenção. As infestações foram reduzidas substancialmente, sem diferença significativa entre as duas técnicas. As infestações finais eram limitadas ao peridomicílio. O equipamento montado em veículo levava menos tempo para completar a aplicação, comparado com o equipamento manual, mas os dois tratamentos tiveram desempenho semelhante e deixaram de suprimir completamente as infestações. As principais vantagens do equipamento montado em veículo foram redução do esforço físico, principalmente em condições adversas em campo, e potenciais ganhos em termos de cobertura de borrifação por unidade de tempo.

Triatoma; Doença de Chagas; Controle de Vetores
Submitted on 23/Jun/2015

Final version resubmitted on 30/Nov/2015

Approved on 21/Jan/2016 